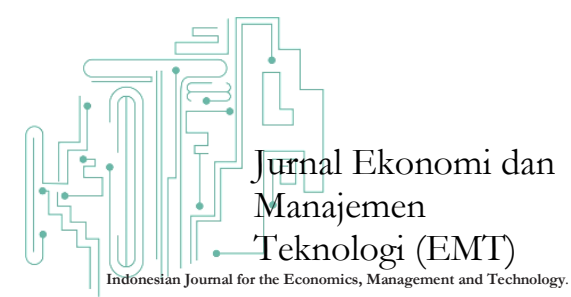

\title{
Analisis Kredit UMKM di Provinsi Aceh: Analisis Empiris Vector Error Correction Model (VECM)
}

\author{
Hamdani $^{1}$, Ismail ${ }^{2}$, Thasrif Murhadi ${ }^{3}$ \\ 1,3 Program Studi: Manajemen Keuangan Sektor Publik \\ (MKSP), Politeknik Kutaraja, Banda Aceh, Indonesia. \\ ${ }^{2}$ Program Studi: Administrasi Perkantoran, Politeknik \\ Kutaraja, Banda Aceh, Indonesia.
}

\begin{abstract}
Abstrak. Tujuan dari penelitian ini adalah untuk mengetahui pengaruh produk domestik regional bruto, non performing loan, dan suku bunga kredit terbadap penyerapan keredit UMKM di Provinsi Aceh. Model analisis time series yang digunakan dalam penelitian ini, terdiri dari, kointegrasi, bivariat dan multivariat kausalitas model Vector Error Correction Model (VECM). Penelitian ini mendokumentasikan babwa pada jangka panjang terdapat hubungan kointegrasi antar variabel yang diteliti. Dalam jangka pendek, variabel produk domestik regional bruto mempengarubi dan memiliki hubungan satu arah dengan kredit UMKM sedangkan variabel suku bunga memiliki hubungan sebab akibat dengan kredit UMKM, sementara variabel NPL tidak memiliki hubungan sebab akibat dengan kredit UMKM untuk meningkatkan peran UMKM dalam pertumbuban ekonomi di Aceh.
\end{abstract}

Kata kunci: Kredit UMKM, Produk Domestik Regional Bruto, Non Performimg Loan, Suku Bunga, Vector Error Correction Model (VECM).

\begin{abstract}
The purpose of this study was to determine the effect of regional gross domestic product, non-performing loans, and loan interest rates on credit absorption by SMEs in Aceh province in the long term. The data used is secondary data in the form of a quarter 1st quarter 1995 to third quarter 2015. The model used in this study is a model of Vector Error Correction Model (VECM) to find out the results of short-term estimates, and using Johansen cointegration test to determine the relationship long-term between variables. The data used in this study has been tested with Augmented Dickey Fuller (ADF) to determine the stationary data. Based on this study it was found that in the long term there is a cointegration relationship between the variables studied. In the short term, the variables affecting the gross regional domestic product and has a one-way relationship with SME loans while variable interest rates have a causal relationship with SME loans in Aceh province, while the NPL variable does not have a causal relationship with SME loans.
\end{abstract}

Keywords: SME Loans, Gross Domestic Product, Non Performimg Loan, Interest Rates, Vector Error Correction Model (VECM).

*Corresponding author. Email: hamdani@poltekkutaraja.ac.id ${ }^{1}$, ismailhamzah14@gmail.com ${ }^{2}$, thasrif.murhadi@gmail.com ${ }^{3}$ 


\section{Pendahuluan}

Berbagai kebijakan negara dalam perekonomian adalah bertujuan untuk menyelesaikan masalah kemiskinan, pengangguran, ketimpangan distribusi pendapatan dan pertumbuhan penduduk. Salah satu upaya pemerintah dalam mengatasi kemiskinan dan pengangguran adalah melalui percepatan sektor rill dan pemberdayaan Usaha Mikro Kecil dan Menengah (UMKM) sebagaimana sesuai dalam Instruksi Presiden (Inpres) Nomor 6 Tahun 2007 tentang paket kebijakan Percepatan Pengembangan Sektor Rill dan Pemberdayaan Usaha Mikro Kecil dan Menengah (UMKM), sehingga UMKM mampu berperan meningkatkan kesejahteraan.

Peran UMKM dalam meningkatkan kesejahteraan masyarakat dapat terlihat pada keterlibatan dalam perekonomian dan pembangunan. Menurut Thesis Flexible Specialization berkembang pada dekade 1980an, seiring dengan berkembangnya perekonomian nasional (daerah), maka keterlibatan UMKM dalam perekonomian daerah tersebut akan semakin penting. Argumen utama Thesis Flexible Specialization adalah UMKM akan berkembang cepat bahkan lebih cepat dari usaha besar dalam proses pembangunan yang sedang berlangsung. Kemunculan Thesis Flexible Specialization ini sekaligus menghapus Teori Klasik tentang peran UMKM dalam pembangunan yang dimotori oleh Hoselitz (1959) dalam Lundvall (1999) dan Anderson (1982) dalam Tambunan (2009) dalam Rifa'i (2010). Teori Klasik tentang peran UMKM dalam pembangunan menyatakan bahwa seiring dengan berkembangnya perekonomian nasional (daerah), maka peran (keterlibatan) UMKM dalam perekonomian daerah tersebut semakin kecil dan tergeser oleh peran usaha besar. Kusnandar (2012) mengatakan kontribusi UMKM secara makro dalam pembangunan dapat dilihat dari beberapa indikator. Pertama, keterlibatan UMKM dalam pembentukan pendapatan per kapita. Kedua, keterlibatan UMKM dalam pembentukan PDRB. Ketiga, keterlibatan UMKM dalam pembentukan pertumbuhan ekonomi daerah (growth).
Menurut laporan Badan Pusat Statistik (2018) menyatakan bahwa peran UMKM di Indonesia secara umum hingga kini terus menunjukan peningkatan yang cukup berarti terutama sekali dari peran kuantitatifnya dalam mempengaruhi aktivitas kegiatan ekonomi hampir di seluruh sektor ekonomi kecuali di sektor minyak dan gas bumi yang banyak ditangani oleh pengusaha besar. Kinerja UMKM yang tetap tumbuh positif pada saat usaha skala besar dan korporasi mengalami penurunan.

Meskipun demikian, laporan BPS Aceh Dalam Angka (2016) juga menyebutkan walaupun perekonomian Aceh selalu mengalami pertumbuhan positif pasca konflik (1989 -2004) dan tsunami (2004), yang ditunjukkan oleh Produk Domestik Regional Bruto (PDRB), sebanyak 6,06 persen pada tahun 2012, namun masih banyak orang miskin di Aceh. Apalagi pertumbuhan PDRB Aceh dengan memasukkan unsur minyak dan gas yang hanya 5,20 persen pada tahun 2012, karena cadangan minyak dan gas yang dimiliki bumi Aceh semakin berkurang. Menurut Badan Pusat Statistik (BPS) Aceh, terdapat 20,98 persen penduduk Aceh yang miskin pada tahun 2010, 19,48 persen 19,48 persen pada tahun 2011, dan 18,58 persen pada tahun 2012.

Dalam kondisi tingginya tingkat kemiskinan, padahal UMKM dapat dijadikan sebagai strategi untuk mengatasi masalah tersebut. Dengan keunggulan yang dimiliki UMKM bisa dijadikan sebagai alternatif untuk membuka lapangan kerja, investasi bahkan bisa meningkatkan gairah eksport yang memungkinkan negara (daerah) memperoleh devisa dan pendapatan. Seperti dikatakan oleh Holcombe (1998), "the engine of economic growth is entrepreneurship." Bahwa UMKM dengan kemampuan entrepreneur nya mampu menjadi penggerak perekonomian, menciptakan pertumbuhan.

Namun pada sisi lain, sebagaimana diketahui bahwa secara internal UMKM juga mengalami berbagai masalah dan kendala seperti, manajemen usaha yang tidak tertib, kapasitas sumber daya manusia yang rendah, lemahnya penguasaan teknologi, permodalan dan kesulitan akses pasar produknya. Menurut survey Bank 
Indonesia (2009) UMKM menginginkan adanya dukungan perbankan di dalam permodalan. Sebanyak 49,3 persen pelaku UMKM memandang perlunya tambahan modal untuk meningkatkan kapasitas usahanya. Dalam kaitan tersebut maka perbankan perlu menyalurkan kredit dan menjalankan fungsi intermediasinya dengan baik demi untuk menciptakan pertumbuhan ekonomi melalui peningkatan kapasitas permodalan UMKM.

Perbankan merupakan sub sistem keuangan yang paling dominan di Indonesia. Setidaknya sekitar 77 persen total pembiayaan sektor rill berasal dari kredit perbankan. Berbagai literatur mempelajari pentingnya peran lembaga perbankan telah ditemukan sejak tahun 1933 seperti Fisher (1933). Stiglizt dan Greenwald (2003) bahkan Pasha (2009) menyatakan bahwa perbankan lebih superior dibandingkan dengan lembaga intermediasi lainnya terutama dalam hal asymmetric information dan mengatasi transaction cost kreditnya. Jika kita melihat realisasi kredit perbankan dari laporan Bank Indonesia (2013) ke sektor UMKM di Provinisi Aceh secara akumulasi tahunan setiap tahun dalam jumlah total terjadi peningkatan.

Menurut Agenol et al., (2000), tidak berfungsinya intermediasi perbankan, khususnya tentang tidak optimalnya penyaluran kredit dapat berasal dari faktor permintaan kredit dan penawaran kredit. Sementara hasil temuan dari Harmanta dan Ekananda (2005), disimpulkan bahwa setelah periode krisis perbankan nasional mengalami excess supply kredit akibat lemahnya permintaan kredit. Sementara Sugema dkk (2009), menyatakan bahwa beberapa penyebab terjadinya kendala intermediasi perbankan adalah melambatnya kemajuan dunia usaha yang ditandai dengan penurunan omset, kendala akses perbankan, serta ekspektasi dunia usaha terhadap perubahan fokus penyaluran kredit oleh perbankan yang terlihat oleh masih tingginya credit rationing perbankan untuk sektor-sektor tertentu.

Dalam menyalurkan kredit, bank memiliki faktor-faktor dari sisi internal perbankan yang mampu mempengaruhi penyaluran kredit, antara lain Non-Performing Loan (NPL), Suku
Bunga Sertifikat Bank Indonesia (SBI), dan Suku Bunga Kredit. Variabel-variabel tersebut sebagai faktor-faktor yang mempengaruhi penawaran kredit. Sedangkan dari sisi eksternal mempertimbangkan perkembangan PDRB sebagai faktor yang mempengaruhi permintaan kredit. Berrospide dan Edge (2010) melakukan penelitian di Amerika Serikat dengan menggunakan data bank holding company (BHC) hasilnya adalah variabel makro ekonomi gross domestic brutto (GDP) berpengaruh signifikan terhadap pemberian kredit. Faktor makro ekonomi (PDRB) juga mempunyai hubungan dengan tingkat penyaluran kredit oleh perbankan di Aceh. Di sisi lain, Das dan Ghosh (2007) secara luas meyakini bahwa munculnya risiko kredit juga memiliki keterkaitan dengan perubahan ekonomi makro yang terjadi. Figlewski et al., (2012) mengatakan faktor ekonomi makro yang memiliki keterkaitan dengan munculnya risiko kredit yaitu, kondisi makroekonomi secara umum yang tercermin dalam inflasi, pergerakan ekonomi yang tercermin dalam pertumbuhan ekonomi (PDRB), dan faktor kondisi keuangan yang tercermin dalam suku bunga. Risiko kredit terkait dengan pertumbuhan perekonomian, dikarenakan dianggap sebagai penentu ekonomi makro dari kinerja bank dan memungkinkan untuk mengendalikan fluktuasi bisnis. Pertumbuhan ekonomi sendiri diukur atas kenaikan nilai seluruh barang dan jasa yang di produksi dan secara signifikan dapat mempengaruhi kemampuan peminjam untuk mengembalikan pinjamannya (Thiagajaran et al., 2011) dalam (Prasetya, 2013). Oleh karena itu, semakin baik kondisi perekonomian suatu daerah yang ditandai dengan PDRB, maka semakin tinggi tingkat permintaan kredit oleh UMKM. Menurut Simaremare dan Hidayat (2013) semakin tinggi PDRB suatu propinsi, maka permintaan kredit pada bank akan semakin tinggi pula. Dengan kata lain variabel makro ekonomi yang stabil juga menjadi faktor yang turut mendorong pemberian kredit UMKM.

Selain itu, kebijakan moneter ideal yang mampu menjaga kestabilan kondisi perekonomian juga memberi impact terhadap keyakinan bagi pihak perbankan untuk melakukan ekspansi kredit dan menambah portofolio. Dengan kebijakan suku bunga yang terjangkau akan memungkinkan 
UMKM untuk menyerap kredit bank secara optimal dengan demikian risiko kegagalan kredit semakin rendah. Hal ini sejalan dengan hasil penelitian Fiore dan Tristani (2013) yang dipublikasi oleh The Economic Journal "Demonstrate that financial frictions affect aggregate dynamics mainly through their impact on firms' financing costs, which increase in both the deposit rate and in the spread between lending and deposit rates"

Dari uraian di atas dapat ditarik suatu pemikiran bahwa kredit UMKM, PDRB, Non-Performing Loan (NPL) dan Suku Bunga merupakan satu sistem yang tergabung dari beberapa sub sistem, di mana pergerakan satu sub sistem akan memberi impact terhadap sub sistem lainnya. Atau dengan kata lain, untuk menjalankan sistem penyaluran kredit UMKM oleh perbankan, maka sub sistem lainnya juga harus digerakkan.

Penelitian tentang kredit UMKM telah dilakukan oleh Anggrahini (2002), Soedarto (2004), Siregar (2006), Andriani (2008) dan Pratama (2010) dalam melihat faktor-faktor yang mempengaruhi (baik sisi permintaan maupun penawaran) terhadap penyaluran kredit UMKM oleh perbankan di Indonesia. Hasil penelitiannya menyatakan bahwa penyerapan kredit UMKM dipengaruhi oleh pertumbuhan ekonomi, suku bunga, inflasi, Dana Pihak Ketiga (DPK), Capital Adequasy Ratio (CAR) dan Non-Performing Loan (NPL), baik berhubungan positif maupun hubungan negatif. Namun menurut hemat penulis, penelitian tersebut terdapat kelemahan karena semuanya menggunakan analisis regresi linear berganda metode ordinary least square (OLS). Sehingga tidak diketahui apakah penyerapan kredit yang mempengaruhi pertumbuhan ekonomi atau pertumbuhan ekonomi yang mempengaruhi penyerapan kredit. Dengan kata lain, apakah terdapat hubungan dua arah? Atau bagaimana pengaruhnya dalam jangka pendek dan jangka panjang?

Selain itu, penelitian yang sama dalam ruang lingkup Provinsi Aceh, sejauh pengetahuan penulis, kuantitasnya masih sangat kurang, apalagi dengan menggunakan pendekatan VECM. Kelebihan pendekatan VECM adalah selain untuk melihat causality dan cointegration antar variabel, bahkan pendekatan VECM memungkinkan untuk menjelaskan bagaimana variabel PDRB, NPL, Suku Bunga dan Penyerapan Kredit UMKM saling mempengaruhi baik dalam jangka pendek maupun jangka panjang. Dengan demikian dalam penelitian ini penulis sangat tertarik untuk menggunakan pendekatan VECM tersebut. Berdasarkan latar belakang di atas, maka penulis melakukan penelitian mengenai: Peran Usaha Mikro Kecil dan Menengah (UMKM) Dalam Penyerapan Kredit di Provinsi Aceh: Analisis Empiris Vector Error Correction Model (VECM).

\section{Studi Kepustakaan}

\section{Usaha Mikro Kecil dan Menengah (UMKM)}

Usaha mikro kecil dan menengah merupakan bentuk kegiatan ekonomi rakyat yang berskala kecil dan memenuhi kriteria kekayaan bersih atau hasil penjualan tahunan serta kepemilikan dan diatur dalam Undang-undang. Menurut UndangUndang No. 20 tahun 2008 tentang usaha mikro, kecil, dan menengah adalah usaha ekonomi produktif yang berdiri sendiri, yang dilakukan oleh orang perorangan atau badan usaha yang bukan merupakan anak perusahaan atau bukan cabang perusahaan yang dimiliki, dikuasai, atau menjadi bagian baik langsung maupun tidak langsung dari usaha menengah atau usaha besar yang memenuhi kriteria antara lain: usaha mikro adalah usaha yang memiliki kekayaan bersih lebih dari Rp50.000.000. tidak termasuk tanah dan bangunan tempat usaha dan memiliki hasil penjualan tahunan lebih dari Rp300.000.000. Sedangkan usaha kecil adalah usaha yang memiliki kekayaan paling banyak Rp50.000.000. sampai dengan paling banyak Rp500.000.000 tidak termasuk tanah dan bangunan tempat usaha; atau memiliki hasil penjualan tahunan paling banyak Rp300.000.000. sampai dengan paling banyak Rp2.500.000.000. Usaha menengah adalah memiliki kekayaan bersih paling banyak Rp500.000.000. sampai dengan paling banyak Rp10.000.000.000. tidak termasuk tanah dan bangunan; atau memiliki hasil penjualan tahunan paling banyak Rp2.500.000.000 sampai dengan paling banyak Rp50.000.000.000. 


\section{Kredit Usaha Mikro Kecil dan Menengah}

Secara etimologis istilah kredit berasal dari bahasa Yunani (credere) yang berarti kepercayaan (truth atau faith), maksudnya adalah apabila suatu pihak memperoleh kredit maka mereka memperoleh kepercayaan. Sedangkan pihak pemberi kredit artinya memberikan kepercayaan kepada seseorang bahwa uang atau barang yang dipinjamkan pasti kembali.

Kredit juga dapat diartikan sebagai hak untuk menerima pembayaran atau kewajiban untuk melakukan pembayaran pada waktu yang diminta atau pada waktu yang akan datang karena penyerahan barang-barang yang sekarang (Kent dalam Ramadhini, 2008). Menurut Mulyono (1990) kredit adalah kemampuan untuk melaksanakan suatu pembelian atau mengadakan suatu pembelian atau mengadakan suatu peminjaman dengan janji pembayaran akan dilakukan/ditangguhkan pada suatu jangka waktu yang disepakati.

Pengertian dari kredit mikro sangat terkait dengan pengertian usaha mikro. Secara universal pengertian kredit mikro adalah definisi yang dicetuskan dalam pertemuan The World Summit in Microcredit di Washington pada tanggal 2-4 Februari 1997 yaitu program atau kegiatan memberikan pinjaman yang jumlahnya kecil kepada masyarakat golongan kelas menengah ke bawah untuk kegiatan usaha meningkatkan pendapatan, pemberian pinjaman untuk mengurus dirinya sendiri dan keluarganya (The World Summit in Microcredit, 2007 dalam Ramadhini, 2008).

Grameen Banking (2003) dalam Ramadhini (2008) mendefinisikan kredit mikro sebagai pengembangan pinjaman dalam jumlah kecil kepada pengusaha yang terlalu rendah kualifikasinya untuk dapat mengakses pada pinjaman dari bank tradisional. Calmeadow (1999) mengartikan kredit mikro sebagai arisan pinjaman modal untuk mendukung pengusaha kecil dalam beraktivitas, umumnya dengan alternatif jaminan kolateral dan sistem monitoring pengembalian. Pinjaman diberikan utnuk melayani modal kerja sehari-hari, sebagai modal awal untuk memulai usaha, atau sebagai modal investasi untuk membeli aset tidak bergerak.
Kredit dibedakan menjadi tiga macam berdasarkan tujuan penggunaannya. Pertama adalah kredit investasi, yaitu kredit yang diberikan kepada nasabah kredit (debitur) untuk membiayai kepentingan barang modal (investasi). Kedua, adalah kredit modal kerja, yaitu kredit yang diberikan kepada nasabah kredit (debitur) untuk membiayai kebutuhan modal kerja perusahaan debitur. Dan yang terakhir, adalah kredit konsumsi, yaitu fasilitas kredit yang diberikan kepada debitur untuk keperluan pembelian barang-barang konsumsi yang diperlukan debitur (Widayati dan Mendari, 2019).

\section{Pertumbuhan Ekonomi}

Pertumbuhan ekonomi diartikan sebagai kenaikan Gross Domestik Product (GDP) tanpa memandang apakah kenaikan itu lebih besar atau lebih kecil dari tingkat pertumbuhan penduduk. Berbicara mengenai pertumbuhan ekonomi tidak terlepas dari pembangunan ekonomi itu sendiri sebab di dalam pertumbuhan ekonomi juga disertai dengan peningkatan kegiatan pembangunan yang mana tujuannya adalah untuk meningkatkan pendapatan perkapita yang tinggi (Sukirno, 2002). Menurut Adi (2006), pembangunan ekonomi ataupun pertumbuhan ekonomi, termasuk pembangunan daerah merupakan proses kenaikan pendapatan masyarakat di suatu daerah dalam jangka panjang. Pendapatan masyarakat di sini lebih ditekankan pada pendapatan riil dan pendapatan masyarakat perkapita orang.

\section{Non-Performing Loan (NPL)}

Menurut Prabowo (2018) NPL merupakan rasio yang digunakan untuk mengukur kemampuan bank dalam meng-cover risiko kegagalan pengembalian kredit oleh debitur. NPL mencerminkan risiko kredit bank, semakin tinggi tingkat NPL, maka semakin besar pula risiko yang akan ditanggung oleh bank. Akibatnya pihak bank harus menyediakan cadangan dana yang lebih besar sehingga dana bank yang disalurkan untuk kredit akan berkurang. Besarnya NPL menjadi salah satu penyebab sulitnya bank dalam menyalurkan kredit.

Menurut teori yang dikemukakan oleh Melitz dan Pardue yang telah disempurnakan oleh 
Warjiyo (2014) dalam Panggalih (2014), NPL juga merupakan faktor yang mempengaruhi penawaran kredit bank. Dalam penyaluran kredit bank akan berusaha memperoleh keuntungan yang besar dengan cara menghindari dan menurunkan tingkat NPL kreditnya. Apabila NPL bank dinilai tinggi, maka reputasi dan keuntungan bank juga akan turun karena masih banyaknya dana kredit yang belum tertagih dari debitur, sehingga dapat mempengaruhi jumlah penawaran kredit bank. Golin (2013), non performing loan (NPL) menggambarkan tingkat kualitas aset suatu bank, yang mana indikator NPL yang baik dapat dibandingkan dengan rata-rata NPL industri bank, jika NPL sebuah bank lebih rendah dari NPL industri, maka dapat dikatakan kualitas aset bank tersebut rendah

\section{Metodologi Penelitian}

Penelitian ini bertujuan untuk mengetahui keseimbangan jangka panjang (cointegration), untuk menguji pengaruh jangka pendek dan jangka panjang dan untuk menguji Bivariate Causality dan Multivariate Causality. Penelitian ini dilakukan di Provinsi Aceh Variabel yang digunakan dalam penelitian ini ada empat yaitu, jumlah penyerapan kredit, Produk Domestik Regional Bruto (PDRB), Non Performing Loan (NPL), dan Suku Bunga. Penelitian ini terbatas pada cointegration, causality dan Vector Error Correction Model (VECM) yang dikembangkan oleh Granger dan Engel (1987).

Adapun jenis data yang digunakan adalah data runtun waktu (time series) dengan periode kuartal mulai periode kuartal 1 tahun 1995 sampai dengan kuartal 3 tahun 2017. Data di peroleh dari Bank Indonesia, Badan Pusat Statistik Provinsi Aceh, OJK (Otoritas Jasa Keuangan), Dinas Koperasi dan UKM Aceh dari instansiinstansi terkait lainnya yang berhubungan dengan penelitian ini Metode penelitian yang digunakan yaitu analisis time series Vector Error Correction Mechanism (VECM) yang merupakan salah satu analisis yang dikembangkan oleh Engle dan Granger (1987) untuk melakukan rekonsiliasi perilaku variabel ekonomi jangka pendek dengan variabel ekonomi jangka panjang (Gujarati, 2003). Konsep penting dalam VECM adalah keseimbangan jangka panjang dari data time series yang sering disebut kointegrasi. Dalam VECM, hubungan jangka pendek antar variabel dalam sistem dipengaruhi oleh deviasi/penyimpangan dari keseimbangan jangka panjang (Enders, 2004).

Selanjutnya adalah melakukan estimasi model VECM melalui beberap pengujian yaitu pertama uji stasioneritas. Asumsi stasioner harus dipenuhi sebelum melakukan estimasi karena apabila data tidak stasioner maka akan menyebabkan timbulnya regresi lancung sehingga sebenarnya metode inferensia klasik tidak dapat diterapkan (Gujarati (1995) dalam Fitriana (2005). Kedua, uji lag optimum yang digunakan untuk menentukan panjang lag optimal yang akan digunakan dalam analisis selanjutnya, karena salah satu kesulitan menggunakan VAR adalah penetapan panjang lag yang optimal. Ketiga, uji Granger Causality yang digunakan untuk mengetahui arah hubungan variabel yang akan diteliti. Hasil uji Granger Causality dapat menunjukkan apakah variabel-variabel yang diteliti memiliki hubungan satu arah (unidirectional causality) atau dua arah (bi-directional causality). Keempat, uji kointegrasi yang dilakukan untuk mendeteksi stabilitas hubungan jangka panjang antara dua variabel atau lebih. Jika series dari variabel-variabel yang diteliti diketahui memiliki unit root, namun kombinasi linier dari variabel-variabel tersebut menghasilkan residual yang stasioner, maka terdapat hubungan jangka panjang (kointegrasi) antar variabel tersebut. Adapun dua series yang terkointegrasi akan memiliki hubungan jangka panjang yang stabil. Menurut Gujarati (2003), pengujian ini hanya valid jika dilakukan pada data asli yang nonstasioner.

Beberapa variabel yang telah digunakan untuk kepentingan penelitian ini memiliki konsep dan definisi sebagai berikut:

1. Penyerapan Kredit

Adalah jumlah total kredit UMKM yang disalurkan oleh perbankan di Provinsi Aceh setiap tahunnya dalam jumlah rupiah.

2. Produk Domestik Regional Bruto (PDRB) Adalah nilai barang dan jasa akhir yang dihasilkan oleh unit produksi di Aceh dan dalam periode satu tahun. Dalam penelitian ini digunakan PDRB Aceh atas dasar harga konstan Tahun 2000 dalam rupiah. 
3. Non Performing Loan (NPL)

Adalah Adalah kredit dengan tingkat kolektibilitas macet yang dihitung setiap tahun dalam jumlah rupiah.

4. Suku Bunga

Suku bunga yang dibebankan oleh perbankan kepada debitur yang dihitung dalam porsentase.

\section{Hasil dan Pembahasan}

Dari hasil penelitian dapat dinyatakan sebagai berikut:

1. Uji Stasioneritas Data (Unit Root Test)

Berdasarkan hasil stasioneritas didapatkan bahwa seluruh variabel tidak stasioner pada derajat level namun setelah dilakukan uji akar unit ulang pada first difference. Hasilnya, semua variabel telah stasioner pada first difference pada tingkat siginifikasni 1\%. Dengan demikian dapat dinyatakan bahwa seluruh variabel penelitian telah stasioner pada diferensiasi pertama (first difference).
Dari hasil uji lag optimal dapat diketahui, bahwa nilai kesalahan prediksi model yang paling kecil adalah dengan metode AIC yaitu sebesar 30,6051 pada lag 5, sedangkan dengan metode SC sebesar 31,2696 dan metode HQ sebesar 30,9438 masingmasing pada 1. Hal ini mengimplikasikan bahwa respon yang ditunjukkan oleh variabel penyerapan kredit UMKM dalam menanggapi perubahan variabel yang menjadi determinannya menurut metode AIC akan terlihat (paling lama) setelah 5 kuartal pasca shock terjadi sedangkan menurut metode SC dan HQ akan terlihat (paling lama) setelah 1 kwartal.

Tabel 2.

\begin{tabular}{cccc}
\multicolumn{4}{c}{ Penentuan Lag Optimal } \\
\hline Lag & AIC & SC & HQ \\
\hline 0 & 38,1469 & 38,2696 & 38,1959 \\
1 & 30,6987 & $31,3121^{*}$ & $30,9438^{*}$ \\
2 & 30,7456 & 31,8496 & 31,1868 \\
3 & 30,8733 & 32,4680 & 31,5106 \\
4 & 30,7027 & 32,7881 & 31,5362 \\
5 & $30,6051^{*}$ & 33,1812 & 31,6346 \\
6 & 30,7483 & 33,8150 & 31,9739 \\
7 & 30,8753 & 34,4327 & 32,2970 \\
\hline
\end{tabular}

Keterangan: * menunjukkan nilai kesalahan prediksi model yang paling kecil

Tabel 1. Hasil Uji Akar Unit Dengan ADF \& PP

\begin{tabular}{ccccc} 
Variabe1 & \multicolumn{3}{c}{ Leve1 } & \multicolumn{2}{c}{ First Difference } \\
\cline { 2 - 5 } & ADF & PP & ADF & PP \\
\hline \multirow{2}{*}{ LPK } & $-1,3169$ & $-1,1141$ & $-10,9937^{* * * *}$ & $-11,0162^{* * * * *}$ \\
& {$[0,6183]$} & {$[0,7069]$} & {$[0,0000]$} & {$[0,0000]$} \\
\multirow{2}{*}{ LPDRB } & $-2,6077$ & $-2,9408$ & $-5,1264^{* * * *}$ & $-8,1643^{* * * *}$ \\
& {$[0,2782]$} & {$[0,1555]$} & {$[0,0000]$} & {$[0,0000]$} \\
\multirow{2}{*}{ LNPL } & $-0,3759$ & $-1,8510$ & $-9,3319^{* * * *}$ & $-14,3736^{* * * *}$ \\
& {$[0,9074]$} & {$[0,3537]$} & {$[0,0000]$} & {$[0,0000]$} \\
SB & $-1,4380$ & $-1,4380$ & $-7,6898^{* * *}$ & $-7,7039^{* * * *}$ \\
& {$[0,1394]$} & {$[0,1394]$} & {$[0,0000]$} & {$[0,0000]$} \\
\hline
\end{tabular}

Keterangan: *** menunjukkan signifikansi pada tingkat $1 \%$

2. Penentuan Lag Optimal

Penetapan lag optimal penting dilakukan karena dalam metode VECM, lag optimal dari variabel endogen merupakan variabel independen yang digunakan dalam model. Dalam menentukan lag length optimal (lag optimal), penelitian ini menggunakan kriteria informasi dengan menggunakan metode Akaike Information Criterion (AIC), Schwarz Criterion (SC) dan Hannan-Quinn (HQ).
Namun demikian, dalam penelitian ini lag optimal yang digunakan adalah berdasarkan hasil metode AIC yaitu lag 5. Harris (1995:65) menjelaskan bahwa jika lag yang digunakan terlalu sedikit, maka residual dari regresi tidak akan menampilkan proses white noise sehingga model tidak dapat mengestimasi actual error secara tepat.

3. Uji Kointegrasi Johansen

Dari hasil estimasi model Johansen dapat diketahui bahwa variabel menunjukkan 
adanya kointegrasi. Hal ini diketahui dari nilai trace statistic pada $\mathrm{r} \leq 0$ lebih besar dari critical value pada tingkat signifikansi 5 persen dan 1 persen. Jika kointegrasi dengan melihat nilai max-eigen statistic dan membandingkannya dengan nilai critical value, maka hasilnya nilai pada $\mathrm{r} \leq 0$ dan $\mathrm{r}$ $\leq 1$ lebih besar daripada critical value pada tingkat signifikansi 5 persen dan terdapat 2 kointegrasi (2 cointegrating equations). Hal ini berarti bahwa hipotesis nol yang menyatakan bahwa tidak ada kointegrasi ditolak dan hipotesis alternatif yang menyatakan bahwa ada kointegrasi tidak dapat ditolak serta hasil estimasi regresi tidak spurious.

Tabel 3.

Hasil Uji Kointegrasi Johansen

\begin{tabular}{|c|c|c|c|c|}
\hline Model & $\begin{array}{c}\text { Null } \\
\text { Hypothesis }\end{array}$ & $\begin{array}{c}\text { Trace } \\
\text { Statistic }\end{array}$ & $\begin{array}{c}5 \text { Percent } \\
\text { Critical Value }\end{array}$ & $\begin{array}{l}1 \text { Percent } \\
\text { Critical Value }\end{array}$ \\
\hline \multirow{4}{*}{$\begin{array}{l}\text { LPK, LPDRB, } \\
\text { LNPL, SB }\end{array}$} & $r \leq 0$ & $57,67 * * *$ & 47,21 & 54,46 \\
\hline & $\mathrm{r} \leq 1$ & 27,00 & 29,68 & 35,65 \\
\hline & $\mathrm{r} \leq 2$ & 4,79 & 15,41 & 20,04 \\
\hline & $r \leq 3$ & 0,94 & 3,76 & 6,65 \\
\hline \multirow[t]{2}{*}{ Model } & $\begin{array}{c}\text { Null } \\
\text { Hypothesis }\end{array}$ & $\begin{array}{c}\text { Max-Eigen } \\
\text { Statistic }\end{array}$ & $\begin{array}{c}5 \text { Percent } \\
\text { Critical Value }\end{array}$ & $\begin{array}{c}1 \text { Percent } \\
\text { Critical Value }\end{array}$ \\
\hline & $r \leq 0$ & $30,66 * *$ & 27,07 & 32,24 \\
\hline \multirow{3}{*}{$\begin{array}{l}\text { LPK, LPDRB, } \\
\text { LNPL, SB }\end{array}$} & $r \leq 1$ & $22,20 * *$ & 20,97 & 25,52 \\
\hline & $\mathrm{r} \leq 2$ & 3,84 & 14,07 & 18,63 \\
\hline & $x \leq 3$ & 0,94 & 3,76 & 6,65 \\
\hline
\end{tabular}

Keterangan: *** dan ** menunjukkan signifikansi masingmasing pada tingkat $1 \%$ dan $5 \%$.

4. Analisis Bivariat Kausalitas Granger (Granger Causality Bivariate Analysis)

Hasil pengujian kausalitas Granger menunjukan bahwa variabel LPDRB memiliki kausalitas satu arah (unidirectional causality) dengan variabel LPK dengan probabilitas sebesar 0,085 pada tingkat signifikansi 10 persen, secara statistik variabel LPDRB memiliki kausalitas signifikan dengan variabel LPK artinya bahwa variabel pertumbuhan ekonomi (PDRB) mempengaruhi secara signifikan tingkat penyerapan kredit, berarti hipotesis nol tidak dapat di tolak. Sedangkan variabel penyerapan kredit secara statistik tidak signifikan memiliki kausalitas dengan variabel pertumbuhan ekonomi (LPDRB) karena probabilitasnya 0,515 yang lebih besar dari alpha 0,05 maka hipotesis nol diterima. Dengan demikian dapat dikatakan bahwa terjadi hubungan searah (uni-directional causality) antara pertumbuhan ekonomi dan penyerapan kredit UMKM yaitu hanya pertumbuhan ekonomi yang secara statistik mempengaruhi penyerapan kredit UMKM. Temuan ini sejalan dengan penelitian sebelumnya yang menyatakan bahwa pertumbuhan ekonomi memiliki hubungan yang kuat dengan penyerapan kredit UMKM.

Tabel 4.

Bivariate Granger Causality Test

\begin{tabular}{lccc}
\hline Null Hypothesis: & Lag & F-Statistic & Prob. \\
\hline LPDRB does not Granger Cause LPK & 5 & $2,029^{*}$ & 0,085 \\
LPK does not Granger Cause LPDRB & & 0,855 & 0,515 \\
\hline LNPL does not Granger Cause LPK & 5 & $1,082^{*}$ & 0,078 \\
LPK does not Granger Cause LNPL & & 1,567 & 0,181 \\
\hline SB does not Granger Cause LPK & 5 & $2,2417 *$ & 0,050 \\
LPK does not Granger Cause SB & & $4,072^{* *}$ & 0,002 \\
\hline LNPL does not Granger Cause LPDRB & 5 & 0,828 & 0,533 \\
LPDRB does not Granger Cause LNPL & 5 & 0,888 & 0,494 \\
\hline SB does not Granger Cause LPDRB & $5,696^{* *}$ & 0,028 \\
LPDRB does not Granger Cause SB & 5 & 0,407 & 0,154 \\
\hline SB does not Granger Cause LNPL & 5 & 0,321 & 0,840 \\
LNPL does not Granger Cause SB & & 0,898 \\
\hline Keterangan: & &
\end{tabular}

Keterangan: ***,** dan * menunjukkan signifikansi pada tingkat $1 \%, 5 \%$ dan $10 \%$.

Hasil pengujian kausalitas granger juga membuktikan bahwa terdapat pengaruh dua arah (bi-directional causality) antara variabel suku bunga (SB) dan variabel penyerapan kredit (LPK), sebab itu hipotesis nol ditolak dengan probabilitas 0,002 dan hipotesis alternatif tidak dapat ditolak. artinya secara statistik bahwa variabel suku bunga (SB) memiliki kausalitas bivariat dengan penyerapan kredit UMKM dan begitu juga sebaliknya SB mempunyai kausalitas dengan LPK dengan probabilitas 0,050. Kausalitas satu arah (uni-directional causality) juga terjadi pada variabel SB dan LPDRB dengan tingkat signifikansi 5 persen atau dengan probabilitas 0,028 , sebab itu hipotesis nol dapat ditolak dan hipotesis alternatif tidak dapat di tolak.

5. Analisis Jangka Pendek dan Jangka Panjang Versi Multivariat Kausalitas (Multivariate Causality Test)

Setelah uji kausalitas antar variabel dilakukan, selanjutnya dilakukan uji F untuk melihat secara simultan (multivariate causality) apakah seluruh variabel independen berpengaruh terhadap variabel dependen. Pengujian ini dilakukan dengan membandingkan nilai F-hitung dengan Ftabel pada tingkat kepercayaan yang digunakan sebesar 1 persen, 5 persen, dan 10 persen sebesar $0,09 \%$. 
Tabel 5.

Multivariate Causality Analysis Versi VECM

\begin{tabular}{|c|c|c|c|c|c|c|}
\hline \multirow{3}{*}{$\begin{array}{c}\text { Dependen } \\
\text { Variabel }\end{array}$} & \multicolumn{6}{|c|}{ Independent Variabel } \\
\hline & \multicolumn{4}{|c|}{ [F-statistik] } & \multirow{2}{*}{$\frac{(\text { t-statistik) }}{\text { ECT }_{\mathrm{t}-1}}$} & \multirow{2}{*}{$\begin{array}{c}\text { Diagnostic } \\
\text { test }\end{array}$} \\
\hline & $\Delta(\mathbf{L P K})$ & $\Delta($ LPDRB $)$ & $\begin{array}{c}\Delta \\
\text { (LNPL) }\end{array}$ & $\Delta(\mathrm{SB})$ & & \\
\hline$\Delta(\mathbf{L P K})$ & - & $\begin{array}{c}3,4608^{* *} \\
{[0,0059]}\end{array}$ & $\begin{array}{l}1,8530^{*} \\
{[0,0986]}\end{array}$ & $\begin{array}{c}7,4295 \text { ***** } \\
{[0,0000]}\end{array}$ & $\begin{array}{c}-0,5285^{* *} \\
(-1,7208)\end{array}$ & $\begin{array}{c}\text { Adj } R^{2=} 0,63 \\
F=3,46^{* *}\end{array}$ \\
\hline$\Delta$ (LPDRB) & $\begin{array}{c}7,7313^{\text {****** }} \\
{[0,0000]}\end{array}$ & - & $\begin{array}{c}0,5550 \\
{[0,7882]}\end{array}$ & $\begin{array}{c}7,2040 \text { ***** } \\
{[0,0000]}\end{array}$ & $\begin{array}{c}-0,7062^{* * * *} \\
(-3,0824)\end{array}$ & $\begin{array}{r}\text { Adj } R^{2=} 0,74 \\
F=7,73^{* * * * *}\end{array}$ \\
\hline$\Delta$ (LNPL) & $\begin{array}{l}1,8530^{*} \\
{[0,0986]}\end{array}$ & $\begin{array}{c}0,5151 \\
{[0,8186]}\end{array}$ & r & $\begin{array}{c}0,5133 \\
{[0,7955]}\end{array}$ & $\begin{array}{c}-0,2845 \\
(-0,4657)\end{array}$ & $\begin{array}{c}\text { Adj } R^{2=}=0,62 \\
F=1,85^{*}\end{array}$ \\
\hline$\Delta(\mathrm{SB})$ & $\begin{array}{l}3,0095^{*} \\
{[0,0132]}\end{array}$ & $\begin{array}{l}7,0452^{\text {* }} \text { *** } \\
{[0,0000]}\end{array}$ & $\begin{array}{c}0,5133 \\
{[0,7955]}\end{array}$ & {$[-3, \pi]$} & $\begin{array}{c}28,3250 * * * \\
(3,75758)\end{array}$ & $\begin{array}{c}\text { Adj } R^{2=}=0,50 \\
F=2,57 *\end{array}$ \\
\hline
\end{tabular}

Keterangan: ***,** dan * menunjukkan signifikansi pada tingkat $1 \%, 5 \%$ dan 10\%. Angka [.] F-statistik dan angka (.) t-statistik. Panjangnya lag length yang digunakan berdasarkan AIC dalam penelitian ini adalah 5 .

Dari hasil analisis kausalitas multivariat dapat diketahui bahwa penyerapan kredit UMKM, pertumbuhan ekonomi, LNPL dan suku bunga secara simultan memiliki pengaruh jangka pendek pada tingkat signifikansi 5 persen. Sedangkan variabel LNPL secara individu memiliki pengaruh jangka pendek pada tingkat signifikansi 10 persen. Sementara variabel suku bunga memiliki pengaruh dalam jangka pendek pada tingkat signifikansi 1 persen terhadap penyerapan kredit.

Sedangkan dalam jangka panjang LPK, pertumbuhan ekonomi, LNPL dan suku bunga menunjukkan bahwa seluruh variabel menuju proses keseimbangan jangka panjang. Hal ini dibuktikan dengan hasil koefesien pada ECT yang signifikan dan negatif dalam model yaitu sebesar -0,5285. Hasil ini juga menjelaskan bahwa tingkat kecepatan penyesuaian (speed of adjustment) sebesar 52,85 persen. Artinya seluruh variabel hanya membutuhkan waktu selama 2,12 kuartal atau 6,36 bulan untuk menuju keseimbangan jangka panjang (konvergen).

\section{Kesimpulan}

1. Berdasarkan hasil uji kointegrasi yang telah dilakukan maka dapat disimpulkan bahwa variabel dalam penelitian ini berkointegrasi. Hasil tersebut mengindikasikan bahwa antara penyerapan kredit UMKM, produk domestik regional bruto, NPL, dan suku bunga memiliki keseimbangan jangka panjang.

2. Dengan menggunakan pendekatan VECM dapat dinyatakan bahwa penyerapan kredit UMKM di Provinsi Aceh pada periode tahun 1995.1 sampai 2015.3 dalam jangka pendek dipengaruhi secara negatif dan signifikan oleh penyerapan kredit tahun sebelumnya. Kemudian dipengaruhi secara positif dan signifikan oleh pertumbuhan ekonomi. Dan demikian juga suku bunga mempengaruhi secara negatif dan signifikan terhadap penyerapan kredit UMKM. Sementara NPL mempengaruhi secara negatif namun tidak signifikan terhadap penyerapan kredit UMKM.

3. Sementara dalam jangka panjang penyerapan kredit dipengaruhi secara positif dan signifikan oleh pertumbuhan ekonomi. Dipengaruhi secara negatif dan signifikan oleh NPL dan dipengaruhi secara negatif dan signifikan oleh suku bunga. Seluruh variabel menuju proses keseimbangan.

4. Hasil pengujian Bivariat Kausalitas Granger menunjukkan bahwa penyerapan kredit memiliki hubungan satu arah dan signifikan dengan pertumbuhan ekonomi. Artinya bahwa pertumbuhan ekonomi mempengaruhi secara signifikan terhadap penyerapan kredit. Sedangkan penyerapan kredit tidak mempengaruhi secara signifikan terhadap pertumbuhan ekonomi atau terdapat hubungan satu arah (unidirectional causality) yaitu pertumbuhan ekonomi mempengaruhi tingkat penyerapan kredit. Hubungan satu arah lainnya ditunjukkan pada pasangan variabel suku bunga dan 
pertumbuhan ekonomi secara signifikan. Artinya pertumbuhan ekonomi secara signifikan mempengauhi tingkat suku bunga. Namun hubungan dua arah (bidirectional causality) secara signifikan terdapat pada pasangan variabel penyerapan kredit dan variabel buku bunga. Hal ini berarti bahwa variabel penyerapan kredit dan suku saling mempengaruhi satu sama lain secara signifikan. Sedangkan hasil pengujian Multivariat Kausalitas Granger menunjukkan bahwa penyerapan kredit memiliki multivariat kausalitas dengan pertumbuhan ekonomi, NPL dan suku bunga. Hal ini dapat dijelaskan bahwa variabel pertumbuhan ekonomi, NPL dan suku sunga berpengaruh secara serentak terhadap penyerapan kredit.

\section{Daftar Pustaka}

Aceh Dalam Angka. (2016). Badan Pusat Statistik. Aceh.

Adi, P. H. (2006). Hubungan antara pertumbuhan ekonomi daerah, belanja pembangunan dan pendapatan asli daerah. Simposium Nasional Akuntansi IX, 23-26.

Anderson, M., \& Holmes, J. (1995). High-skill, low-wage manufacturing in North America: A case study from the automotive parts industry. Regional Studies, 29(7), 655-671.

Andriani, S. (2008). Analisis Faktor-Faktor Yang Mempengaruhi Volume Penyaluran Kredit Mikro, Kecil Dan Menengah (MKM) Di Indonesia. Skripsi Pada Departemen Ilmu Ekonomi. Fakultas Ekonomi dan Manajemen, Institut Pertanian Bogor.

Anggrahini, Dewi. (2002). Analisis Faktor Faktor yang Mempengaruhi Penyaluran Kredit Perbankan pada Bank Umum di Indonesia Periode 1994.1 -2003.4. Tesis.

Bank Indonesia. (2013). Bank Indonesia Bank Sentral Republik Indonesia: Tinjauan Kelembagaan, Kebijakan, dan Organisasi.
Jakarta: Pusat Pendidikan dan studi Kebanksentralan.

Bank Indonesia. Kajian Ekonomi Regional Provinsi Aceh. Berbagai Edisi.

Berrospide, J. M., \& Edge, R. M. (2010). The effects of bank capital on lending: What do we know, and what does it mean?

Das, A., \& Ghosh, S. (2007). Determinants of credit risk in Indian state-owned banks: An empirical investigation.

Enders, W. (2004). Applied Econometric Time Series Second Edition. Hoboken: John Willey and Son, Inc.

Engle, R.F. dan C. W. J. Granger. (1987). Cointegration and Error Correction: Representation, Estimation, and Testing, Econometrica, Vol. 55, No. 2, March 251279.

Figlewski, S., Frydman, H., \& Liang, W. (2012). Modeling the effect of macroeconomic factors on corporate default and credit rating transitions. International Review of Economics \& Finance, 21(1), 87-105.

Fiore dan Tristani, Oreste. (2013). Optimal Monetary Policy In a Model of Credit Channel. Volume 123, Issue 571(906931). The Economic Journal.

Fisher, I. (1933). The debt-deflation theory of great depressions. Econometrica: Journal of the Econometric Society, 337-357.

Fitriana, Y. (2005). Penanaman Modal Asing Langsung dan Hubungannya dengan Beberapa Indikator Makro Ekonomi Tahun 1989-2004. Jakarta: Sekolah Tinggi Ilmu Statistik.

Golin, J., \& Delhaise, P. (2013). The bank credit analysis handbook: a guide for analysts, bankers and investors. John Wiley \& Sons.

Gujarati, D. (1995). Basic Econometrics Third \& Fourth edition. New York: McGrawHill. 
Gujarati, D. (2003). Basic Econometrics Third $\&$ Fourth edition. New York: McGrawHill.

Gujarati, N. Damodar, (2003), Ekonometrika Dasar, Terjemahan. Jakarta Green.

Harmanta, H., \& Ekananda, M. (2005). Disintermediasi fungsi perbankan di Indonesia pasca krisis 1997: Faktor permintaan atau penawaran kredit, sebuah pendekatan dengan model disequilibrium. Buletin Ekonomi Moneter dan Perbankan, 8(1), 51-78.

Harris, R. (1995). Cointegration Analysis in Econometric Modelling. New York:Prentice Hall.

Holcombe, R. G. (1998). Entrepreneurship and economic growth. The Quarterly Journal of Austrian Economics, 1(2), 4562.

Hoselitz, B. F. (1959). Economic Policy and Economic Development.

Kusnandar, (2012). Analisis Faktor-faktor Yang Mempengaruhi Pemberian Kredit UMKM oleh Perbankan di Indonesia, Universitas Indonesia.

Lundvall, B. A. (1999). National business systems and national systems of innovation. International Studies of Management \& Organization, 29(2), 6077.

Mulyono, S., \& RM Sudikno Mertokusumo, S. H. (1990). Peranan kredit konstruksi dalam pembangunan perumahan di Propinsi Daerah Istimewa Yogyakarta (Doctoral dissertation, [Yogyakarta]: Universitas Gadjah Mada).

Panggalih, (2015). Analisis Pengaruh Dana Pihak Ketiga (DPK), Non-Performing Loan (NPL), Suku Bunga Sertpikat Bank Indonesia (SBI), dan Suku Bunga KUR Terhadap penyaluran Kredit Usaha Rakyat (KUR). Jurnal Ilmiah.
Prabowo, E. S., Kristianti, F. T., \& Dillak, V. J. (2018). Pengaruh Non-Performing Loan (Npl), Capital Adequacy Ratio (Car), Dan Bi Rate Terhadap Penyaluran Kredit Perbankan (Studi Pada Perbankan Yang Terdaftar Di Bursa Efek Indonesia Periode 2012-2016). eProceedings of Management, 5(1).

Prasetya, S. G. (2017). The Effects of Capital, Profitability, Liquidity Upon the Prediction of National Bank Fragility. The Accounting Journal of Binaniaga, 2(01), 59-72.

Pratama, B. A. (2010). Analisis faktor-faktor yang mempengaruhi kebijakan penyaluran kredit perbankan (Studi pada Bank Umum di Indonesia Periode Tahun 2005-2009) (Doctoral dissertation, Universitas Diponegoro).

Ramadini, W. P., Mardani, R. M., \& Wahono, B. (2018). Pengaruh Capital, Asset Quality, Management, Earning, Liquidity Terhadap Pertumbuhan Laba (Study Empiris Pada Bank Umum Swasta Nasional Yang Tercatat Di Bursa Efek Indonesia). Jurnal Ilmiah Riset Manajemen, 7(11).

Rifa'i, A. (2010). Peran UMKM Dalam Pembangunan Daerah:Fakta di Provinsi Lampung. Jurnal Ilmiah Administrasi Publik dan Pembangunan, Vol.1,No.2.

Rifa'i, A. (2010). Peran UMKM dalam pembangunan daerah: fakta di Provinsi Lampung. Jurnal Ilmiah Administrasi Publik dan Pembangunan ADMINISTRATIO, 1(2), 133-143.

Siregar, T. (2006). Analisis Faktor-Faktor yang Mempengaruhi Permintaan Kredit pada Bank Pemerintah di Sumatera Utara (Master's thesis).

Soedarto, M. (2004). Factor that affects distribution rural credit bank [BPR (rural bank) case study in work area bank Indonesia Semarang] (Doctoral dissertation, Thesis. Magister Management 
Study Program Diponegoro University, Semarang).

Statistik Usaha Mikro Kecil dan Menengah (UMKM). Website : www.depkop.go.id; E-Mail : bagdat@depkop.go.id

Sugema, I., Bakhtiar, T., \& Effendi, J. (2009). Keunggulan sistem keuangan berbasis bagi hasil dan implikasinya pada distribusi pendapatan. Jurnal Keuangan dan Perbankan, 13(3).

Sukirno, Sadono. (2002). Pengantar Teori Mikro Ekonomi. Jakarta: PT Grafindo Persada.

Sukirno, Sadono. (2005). Mikro Ekonomi Teori Pengantar edisi ketiga. PT. Rajagrafindo Persada: Jakarta.

Sukirno, Sadono. (2006). Mikro Ekonomi Teori Pengantar. Edisi Ketiga. Jakarta: Rajagrafindo Persada.
Tambunan, T. T. H. (2009). SME Development Pattern: A Theoretical Consideration. In SMEs in Asian Developing Countries (pp. 17-36). Palgrave Macmillan, London.

Thiagarajan, S., Ayyappan, S., \& Ramachandran, A. (2011). Credit risk determinants of public and private sector banks in India. European Journal of Economics, Finance and Administrative Sciences, 34(34), 147-153.

Warjiyo, P. (2004). Mekanisme Transmisi Kebijakan Moneter di Indonesia. Buku Seri Kebanksentralan, (11).

Widayati, R., \& Mendari, W. E. (2019). Upaya Penanganan Kredit Bermasalah Pada Bank Nagari Cabang Utama Padang. 